\title{
A DEBRECENI ÖNKORMÁNYZAT KÖLTSÉGVETÉSÉNEK SAJÁTOSSÁGAI, 1992-1998
}

\author{
(The Characteristics of the Budget of the Local Government \\ of Debrecen)
}

\section{KOZMA GÁBOR}

\section{Bevezetés}

A rendszerváltás után újonnan létrejött önkormányzatok a gazdálkodás területén megváltozott feltételekkel voltak kénytelenek szembenézni. Teljesen új jogszabályok rendezték a müködésükre vonatkozó alapvető kérdéseket, költségvetésük bevételi és kiadási szerkezete nagymértékben átalakult, és a korábbi időszakhoz képest megnött a települések gazdasági önállósága. Az új körülmények természetesen nem egyformán érintették az egyes településeket, és az eltérö történelmi hagyományok, gazdasági adottságok, a térségben betöltött szerepkör hatására jelentős különbségek alakultak ki közöttüik.

Tanulmányunk célja Debrecen 1992-98 közötti költségvetése alakulásának bemutatása, és ezzel összefüggésben arra a kérdésre keressük a választ, milyen tényezökre vezethetők vissza a költségvetés bevételi és kiadási oldalán megfigyelhetö, az országos értékektöl eltérő adatok?

Az elemzés során kétfajta módszert használtunk. Egyrészt azt vizsgáltuk, hogyan változik az adott bevételtípusnak illetve kiadási tételnek az összbevételböl (összkiadásból) való részesedése, és ez hogyan alakul az országos értékhez képest ( 1 . és 3. táblázat). Így arról szereztünk ismereteket, hogy az adott bevétel szerepe nagyobb vagy kisebb, mint országos viszonylatban. Másrészt az egyes bevétel- és kiadástípusoknál mind debreceni, mind országos viszonylatban kiszámoltuk az egy före jutó értéket, és így az adott bevétel debreceni relatív nagyságáról szereztünk információkat (1. és 3. táblázat).

\section{A bevételi oldal jellegzetességei}

A hét nagy bevételi típus (saját folyó bevételek, felhalmozási és tőkebevételek, átengedett bevételek, állami hozzájárulások és támogatások, Társadalombiztosítástól átvett pénzösszegek, egyéb átvett pénzösszegek és visszatérítések, hitel- és kötvénybevételek) jelentőségét, az összbevételből való részesedését a hét év átlagában elemezve megállapítható, hogy az állami hozzájárulások és támogatások, valamint a hitel- és kötvénybevételek részesedése jelentösen meghaladta az országos értéket, a Társadalombiztositástól átvett pénzeszközök aránya viszont nagymértékben elmaradt attól, míg a másik négy forrásnál nincs lényeges eltérés. 


\section{TÁBLÁZAT}

A magyarországi önkormányzatok és a debreceni önkormányzat egyesített költségvetésének bevételi oldala (az 1992-98 közötti évek átlaga, 1992-es áron számolva, a fogyasztói árindexet felhasználva)

(The Receipt Side of the Budget of the Hungarian Local Governments and the Local Government of Debrecen, Average of the Years 1992-1998, Adjusted to the Prices of 1992 with the Consumer Price Index)

\begin{tabular}{|c|c|c|c|c|}
\hline & \multicolumn{2}{|c|}{ A } & \multicolumn{2}{|c|}{ B } \\
\hline & $\begin{array}{l}\text { Magyar- } \\
\text { ország }\end{array}$ & Debrecen & $\begin{array}{l}\text { Magyar- } \\
\text { ország }\end{array}$ & Debrecen \\
\hline 1. Saját folyó bevételek & 19,7 & 21,3 & 8806 & 7540 \\
\hline 1.1. helyi adók & 6,5 & 6,3 & 2937 & 2237 \\
\hline 1.2. illetékbevételek & 1,6 & 2,2 & 694 & 776 \\
\hline 1.3. kamatbevételek & 2,1 & 0,2 & 924 & 86 \\
\hline 1.4. intézményi tevékenység bevételei & 8,2 & 10,9 & 3688 & 3851 \\
\hline 1.5. egyéb saját folyó bevételek & 1,3 & 1,7 & 563 & 591 \\
\hline 2. Felhalmozási és tỏkebevételek & 10,5 & 9,1 & 4714 & 3219 \\
\hline $\begin{array}{l}\text { 2.1. tárgyi eszközök és ingatlanok érté- } \\
\text { kesítése }\end{array}$ & 4,4 & 4,6 & 1970 & 1618 \\
\hline 2.2. értékpapírok értékesítése & 2,3 & 2,1 & 1020 & 764 \\
\hline 2.3. privatizáció, vállalatértékesítés & 0,9 & 1,0 & 379 & 370 \\
\hline 2.4. egyéb felhalmozási és tökebevételek & 3,0 & 1,3 & 1344 & 467 \\
\hline 3. Átengedett bevételek & 11,3 & 13,6 & 5059 & 4817 \\
\hline 3.1. SZJA & 10,8 & 12,9 & 4834 & 4577 \\
\hline 3.2. gépjármủadó & 0,5 & 0,7 & 225 & 240 \\
\hline 4. Állami támogatás és hozzájárulás & 37,3 & 42,8 & 16696 & 15116 \\
\hline 4.1. normatív állami hozzájárulás & 27,7 & 35,9 & 12400 & 12646 \\
\hline 4.2. címzett és céltámogatás & 3,2 & 0,8 & 1443 & 283 \\
\hline 4.3. SZJA-kiegészítés & 0,5 & 0 & 237 & 0 \\
\hline $\begin{array}{l}\text { 4.4. müködésképtelenné vált önkormány- } \\
\text { zatok kiegészító támogatása* }\end{array}$ & 0,6 & 0 & 258 & 0 \\
\hline 4.5. központositoft elöirányzatok & 3,4 & 5,0 & 1519 & 1776 \\
\hline 4.6. egyéb támogatás és hozzájárulás & 1,9 & 1,2 & 835 & 411 \\
\hline $\begin{array}{l}\text { 5. Társadalombiztosítástól átvett pénz- } \\
\text { eszközök }\end{array}$ & 15,3 & 4,6 & 6848 & 1633 \\
\hline $\begin{array}{l}\text { 6. Egyéb átvett pénzeszközök, visszatéri- } \\
\text { tések }\end{array}$ & 3,1 & 2,8 & 1367 & 994 \\
\hline 7. Hitel, kötvény bevétel & 2,8 & 5,8 & 1268 & 2037 \\
\hline Tárgyévi bevételek & 100,0 & 100,0 & 44757 & 35359 \\
\hline
\end{tabular}

* 1994-ig önhibáján kívül hátrányos helyzetbe került önkormányzatok kiegészitö támogatása A - az egyes bevételi típusok részesedése az összbevételböl (\%), B - az adott bevételi típus egy lakosra jutó értéke ( $\mathrm{Ft} /$ /ö)

Forrás: Keményné Koncz 1993; Szelényi 1994; Birkásné Tóth-Szelényi 1995; DobosnéSzelényi 1996; 1997; 1998; és a debreceni önkormányzat költségvetési rendeletei.

A saját folyó bevételek összbevételböl való részesedése kismértékben felülmúlta az országos értéket, figyelemreméltó, és a város rosszabb anyagi helyzetére utal ugyanakkor az a tény, hogy az egy före jutó érték elmarad attól. Ezen forrás igen jelentôs, és az 1990-es évek folyamán egyre fontosabb szerepet betöltő részét alkotják a helyi adók, amelyeknél egy igen jelentös időbeli változást is meg lehet figyelni. Az 1990-es évek elején részesedésük még kisebb volt, mint az országos 
érték (1993-ban 4,7\% ill. 3,9\%), az egy före jutó érték pedig annak 2/3-át érte el, az 1990-es évek második felében azonban szerepe és fontossága ugrásszerüen megnövekedett (1998-ban az összbevételböl való részesedése már 14,2\% volt). A változás igen szoros kapcsolatot mutatott az egyes helyi adótípusok jelentỏségével illetve az alkalmazott adókulcsokkal.

Az 1990-es évek elején az önkormányzat valamennyi kivethetỏ adótípust alkalmazta, és egy többé-kevésbé kiegyensúlyozott, mind a lakosságot, mind a helyi vállalkozókat megterhelö adószerkezet volt megfigyelhetö. Ebben az időszakban részben a politikai népszerütlenségtỏl tartva - még igyekezett az adókulcsokat alacsonyan tartani, és azok a törvényekben meghatározott maximális érték 50-65\%-át érték csak el.

Az 1990-es évek második felére azonban jelentősen megváltozott a helyzet. Az önkormányzat ekkorra már minden egyéb számba vehetỏ lehetőséget kihasznált (lakások, beépítetlen telkek és részvények eladása, hitelek felvétele, kötvények kibocsátása), és más megoldás hiányában kénytelen volt nagyobb mértékben a helyi adókra támaszkodni. Minden adónem esetében emelést hajtott végre (erre alkalmat kínált az a tény, hogy az országgyủlés is megemelte a törvényileg kivethetö maximális értékeket), ez azonban differenciált mértékủ volt: kisebb mértékben érintette a lakosságot (ide lehet sorolni a telekadót, az építményadót és az 1994-töl megszünt magánszemélyek kommunális adóját) és nagyobb mértékben a vállalkozókat (a vállalkozók kommunális adója elérte a törvényben meghatározott maximumot, és a helyi iparüzési adó is csak 1-2 ezrelékkel maradt el attól). Ennek hatására 1998-ra (az országos trendeket követve) abszolút fölénybe kerültek a vállalkozókat terhelö adók (1998-ban a helyi adókból befolyó jövedelem 3,4\%-át tette ki a vállalkozók kommunális adója és $85,5 \%$-át az iparüzési adó).

\section{TÁBLÁZAT}

Helyi adók megoszlása Magyarországon és Debrecenben (\%, az 1992-98 közötti évek átlaga, 1992-es áron számolva, a fogyasztói árindexet felhasználva)

(The Distribution of Local Taxes in Hungary and Debrecen, in percentage. Average of the Years 1992-1998, Adjusted to the Prices of 1992 with the Consumer Price Index)

\begin{tabular}{lcc}
\hline & Magyarország & Debrecen \\
\hline Építményadó & 9,6 & 13,3 \\
Telekadó & 1,7 & 2,4 \\
Magánszemélyek kommunális adója & 4,0 & 0,5 \\
Vállalkozók kommunális adója & & 7,6 \\
Idegenforgalmi adó & 2,6 & 0,7 \\
Iparủzési adó & 81,9 & 75,5 \\
Egyéb adók & 0,2 & 0 \\
Összesen & 100,0 & 100,0 \\
\hline
\end{tabular}

Forrás: Világgazdaság 2000. január 15.; a debreceni önkormányzat költségvetési rendeletei.

$\mathrm{Az}$ országos folyamatoktól a legnagyobb eltérés (elmaradás) az idegenforgalmi adó tekintetében mutatkozott. Ennek hátterében az állt, hogy Debrecen saját maga nem rendelkezik igazán nagyarányú bevételt hozó idegenforgalommal: üdülésre alkalmas hétvégi telek alig található a város területén, a városba látogató turisták 
jelentős része Hajdúszoboszlón száll meg, igy ez az adótipus az országosnál sokkal alárendeltebb szerepet töltött be a város bevételei között.

A saját folyó bevételek másik lényeges összetevőjét az intézményi tevékenységek bevételei alkotják, amelyekhez az önkormányzati fenntartású oktatási, kulturális, sport stb. intézményekben keletkezett források (például belépöjegyek, téritési dijak) tartoznak. Ezen forrás részesedése az összbevételböl Debrecenben minden évben meghaladta az országos értéket, és az egy före jutó összeg is nagyobb volt annál. Ennek hátterében az áll, hogy a város érintett intézményhálózata nemcsak a helyi lakosság, hanem a vonzáskörzet, illetve bizonyos esetekben az egész megye igényeit elégiti ki, és ez egy jelentős nagyságú és nagy bevételt hozó intézményhálózatot eredményezett.

$\mathrm{Az}$ illetékbevételeknek az országosnál nagyobb szerepe elsősorban az adott forrás sajátosságaival van összefüggésben. A központi költségvetési törvények szerint a megyei jogú városok és Budapest önkormányzata megkapják a területükön beszedett illetékek 50\%-át, míg a megye többi településén beszedett illetékek 50\%-a a megyei önkormányzatok bevételeit növeli. Az illetékek különbözö típusainak (ajándékozási, öröklési, visszterhes vagyonátruházási, bírósági eljárási, államigazgatási eljárási illeték) ismeretében egyáltalán nem meglepö, hogy ez a bevételi forrás a nagyobb ingatlanárakkal rendelkezỏ, illetve bizonyos eljárásokra (például bírósági tárgyalás, útlevél kiadás) jogosult nagyvárosokban fontos szerepet játszik.

A debreceni önkormányzat relatív szegénységére utal a kamatbevételek minimális, az országosnál lényegesen kisebb jelentősége. Az elmúlt időszakban ugyanis az önkormányzatnál a szorító pénzügyi feltételek miatt csak korlátozottan nyilt lehetöség arra, hogy a szabad pénzeszközöket hosszú távú lekötés keretében a bankba tegyék, és így kamatbevételre tegyenek szert.

A felhalmozási és tökebevételek szerepe kisebb volt az országosnál, és az egy före jutó átlagos érték is az alatt maradt. Az ide sorolható bevételi források közül háromban (tárgyi eszközök és ingatlanok értékesítése, részvények és értékpapírok értékesítése, privatizáció és vállalatértékesítés) a hét év átlagát tekintve nem mutatkozott jelentős eltérés az országos adatoktól, a különbség fö oka az egyéb felhalmozási és tökebevételekben keresendö. Az egyes évek vonatkozásában ugyanakkor igen jelentős ingadozásokat lehet megfigyelni, amely azzal magyarázható, hogy az önkormányzat rendkívül szélsőségesen és rövid idő alatt élt a kínálkozó bevételi lehetőségekkel.

Az 1990-es évek elején a legnagyobb figyelmet a tárgyi eszközök és ingatlanok értékesítésére fordították. Az 1990-es önkormányzati (1990. évi 65. törvény) és az 1991-es vagyontörvény (1991. évi 33. törvény) eredményeként az önkormányzat igen jelentős (kb. 24000 darabból álló) lakásvagyonhoz jutott, amelynek kb. az 50\%-a az 1993-as lakástörvény (1993. évi 78. törvény) elöírásait követve 1995 végére eladásra került. Az 1990-es évek második felében ugyanakkor már nagyobb figyelmet kapott a beépítetlen ingatlanok eladása. Ennek hátterében az állt, hogy a városban letelepedni kívánó multinacionális kereskedelmi cégek (például TESCO, CORA) igényeinek kielégítése, valamint a nagy bevásárlóközpontok (például Deb- 
recen Plaza, Malompark) felépítése érdekében a város nagyarányú telekértékesítésbe kezdett.

A részvények és értékpapírok értékesitése az elöző kategóriához hasonló idöbeli ingadozást mutatott. Az első kisebb csúcsot 1992-ben lehetett megfigyelni, amikor az önkormányzat a tulajdonába került ipari vállalati részvényeket (pl. Dohánygyár, Debreceni Húsipari Rt.) adta el. Az elözönél sokkal jelentősebb bevételt biztosított ez a forrás az 1990-es évek második felében, amikor az önkormányzatok hozzájutottak a területiikön múködő gáz- és áramszolgáltató vállalatok részvényeinek egy részéhez (a gázszolgáltatóknál 40\%, az áramszolgáltatóknál 12,5\%). A debreceni önkormányzat a szorító pénzügyi viszonyok miatt arra kényszerült, hogy a megkapott TITÁSZ és TIGÁZ részvényeket rövid idő alatt eladja, és így enyhítsen anyagi gondjain (1996-ban a részvények és értékpapírok részesedése az összbevételböl $6,1 \%$ volt).

Az egyéb felhalmozási és tökebevételek esetében megfigyelhetö elmaradás alapvetően ezen bevételtípus jellegéböl adódik: ide tartoznak az államháztartáson kívülröl illetve belülröl átvett fejlesztési célú pénzek (pl. a lakossági befizetések az ivóvíz-, szennyvíz- és gázhálózat kiépítése érdekében, illetve az elkülönített állami alapoktól és a minisztériumi fejezetektől fejlesztésre kapott összegek). Az elöbbi szerepe azért volt kisebb, mert Debrecen - a rendszerváltás elötti fejlesztéseknek köszönhetöen - egy megfelelö színvonalú vonalas infrastruktúrával rendelkezett (1991-ben a vezetékes gázhálózatba kapcsolt lakások aránya 59,9\%, a vezetékes ivóvízhálózatba kapcsolt lakások aránya $98,9 \%$, a szennyvízhálózatba bekapcsolt lakások aránya pedig $71,6 \%$ volt, míg a megfelelö országos adatok $41,9 \%, 85,1 \%$ és 41,7\% voltak). Az 1990-es évek során történtek ugyan fejlesztések ezen a területen a lakossági pénzek bevonásával, ennek mértéke azonban kisebb volt, mint országos viszonylatban.

Az utóbbi (államháztartáson belülről átvett fejlesztési célú pénzek) esetében az elmaradást alapvetően Debrecen igen gyenge érdekérvényesítési képessége magyarázza. 1990 és 1998 között a várost az országos politikában súlytalannak tekinthetö személyek irányították, illetve az országos vezetők között sem volt igazán debreceni kötődésủ, és ezért a település csak korlátozottan jutott hozzá központi fejlesztési pénzekhez.

$\mathrm{Az}$ átengedett (megosztott) bevételek közé a személyi jövedelemadó (SZJA) önkormányzatok számára visszajuttatott része és a gépjármüadó tartozik. A bevételek döntő részét képező $S Z J A$ esetében világosan megállapítható, hogy ez a forrás a város költségvetésében fontosabb szerepet játszott, mint országos viszonylatban. Ennek hátterében a debreceni magasabb keresetek állnak: a megyeszékhelyi illetve regionális központi szerepkör következtében több olyan intézmény is múködik a városban, amelyek az országos átlagnál magasabb fizetést tudnak biztosítani (1998ban például Debrecenben az egy állandó lakosra jutó SZJA 62830 Ft volt, szemben az országos $59769 \mathrm{Ft} /$ fö értékkel).

Az időben elörehaladva ugyanakkor az a trend is megfigyelhetö, hogy az SZJA bevételnek az összbevételböl való részesedését tekintve fokozatosan csökkent a különbség a debreceni és az országos adatok között (1992: 2,9\%, 1993: 2,8\%, 1994: 2,8\%, 
1995: 1,7\%, 1996: 1,2, 1997: 1,9\%, 1998: 1,6\%), illetve az egy lakosra jutó SZJA bevétel nagysága Debrecenben egyre inkább elmaradt az országos értéktől (1993ban még annak 110, míg 1998-ban csak 83,3\%-a). Ezen folyamatok hátterében az a központi kormányzati tevékenység állt, amely fokozatosan csökkentette a településekhez visszajuttatott SZJA-n belül a közvetlenül a befizetés helyére visszakerülő SZJA arányát, és növelte az egyéb (gyakran normatív) módszerekkel elosztott összegek arányát, és ez a trend Debrecen számára - hasonlóan a többi nagyvároshoz - a legtöbb esetben hátrányos volt.

A gépjármüadó, mint átengedett bevétel (a beszedett adó 50\%-a a központi költségvetésbe kerül) esetében világosan tükrözödik, hogy ez a forrás Debrecenben fontosabb szerepet játszott, mint országos viszonylatban: a Hajdú-Bihar megyei megyeszékhelyen részesedése az összbevételböl nagyobb, mint az országos adat, és a legtöbb évben az egy före jutó érték is felülmúlta azt. Ez azzal magyarázható, hogy Debrecenben a gépkocsi-ellátottság kismértékben jobb, mint országos szinten, és ezért a gépkocsik súlya után fizetett adóból is több folyt be.

Az állami hozzájárulások és támogatások 1992 és 1998 között Debrecenben az összbevételből az országosnál sokkal nagyobb arányban részesedtek, és ennek hátterében az ezen bevételi forrás döntő részét alkotó normativ állami hozzájárulások álltak (itt még nagyobb volt az eltérés). Ezen összegeket ugyanis az önkormányzatok különböző mutatók (például általános és középiskolások száma, kollégiumi férőhelyek száma) alapján az oktatási-kulturális-szociális intézmények müködtetésére kapják. Debrecen - mint már korábban emlitettük - jelentös megyei és regionális feladatokat is ellátó intézményhálózattal rendelkezik, amely után nagy összegü hozzájárulást kap a központi költségvetésből. Igen nagy problémát jelent ugyanakkor az a tény, hogy ez a pénz a legtöbb esetben nem elegendỏ az érintett intézmények müködési költségeinek a fedezésére. A normativ állami hozzájárulások döntő részét (1998-ban kb. 75\%-át) kitevő oktatási normativák például Debrecenben 1992-ben a müködési kiadások 74,1\%-át, 1995-ben 47,9\%-át, 1997-ben pedig $54,8 \%$-át fedezték, és a hiányzó összeget az önkormányzatnak egyéb forrásaiból kellett biztosítania.

A város az elmúlt években igen mérsékelten részesedett a cél-és címzett támogatásokból: ezen forrás összbevételen belüli aránya egyik évben sem érte el az országos átlagot, csak három évben haladta meg az 1\%-ot, és az egy före jutó érték is végig az országos alatt maradt. Az 1992-es, az 1996-os és 1997-es relatíve magasabb arányok annak tulajdoníthatók, hogy ezekben az években Debrecen iskola- és tornaterem-építésre, valamint a szennyviztisztító-telep bővítésére kapott ,jelentősebb" összegeket.

A lemaradás mögött véleményünk szerint három ok áll. Egyrészt a céltámogatások elsösorban a kisebb településeken lezajló vízgazdálkodási, oktatási-kulturális, egészségügyi-szociális és hulladékkezelési beruházásokat voltak hivatva segíteni, és így Debrecen csak korlátozottan részesedett belölük. Másrészt a címzett támogatások föleg a térségi célokat szolgáló fejlesztéseket támogatták, és Debrecenben ezek gyakran a megyei önkormányzat tulajdonában lévő intézményekben valósultak meg (például a Kenézy Gyula Kórház új szárnyának felépítése). Harmadrészt 
problémát okozott az önkormányzat - már korábban említett - gyenge érdekérvényesítö-képessége is.

A hét év adatait vizsgálva megállapítható, hogy Debrecen nem részesült $S Z J A$ kiegészítésben, illetve a müködésképtelenné vált önkormányzatok kiegészítö támogatásában (1994-ig az önhibáján kívül hátrányos helyzetbe került önkormányzatok kiegészítő támogatása). Ez azzal magyarázható, hogy a városban az egy före jutó SZJA nem érte el a szükséges minimális szintet, illetve a város költségvetése nem került olyan rossz anyagi helyzetbe, hogy Debrecen jogosult lett volna ezekre a támogatási formákra.

A központositott elöirányzatok azon támogatási formákat jelölik, amelyek megvalósítását a kormányzat valamilyen oknál fogva fontosnak tartja. Ezeknek a köre évröl évre változott, és így egyes években Debrecen számára elönyösebb, más években hátrányosabb támogatási formák kerültek bele. Az 1994-96 közötti magasabb értékeket az a tény magyarázza, hogy ezekben az években a köztisztviselöiközalkalmazotti bérek bevezetésének támogatása a központosított elöirányzatok közé tartozott, és Debrecen így jelentös összegekben részesült.

A Társadalombiztositástól (pontosabban az Egészségbiztositási Alaptól) átvett, és a debreceni önkormányzat irányítása alatt álló egészségügyi intézmények müködési kiadásainak fedezését szolgáló pénzösszegek vonatkozásában megfigyelhető nagymértékü különbség az első pillanatban - figyelembe véve a megyeszékhely regionális szerepkörét - megmagyarázhatatlannak tünik. Az elmaradás alapvetően az érintett intézmények (Kenézy Gyula Kórház, Debreceni Orvostudományi Egyetem, 2000. január 1-től a Debreceni Egyetem Általános Orvostudományi Kara) tulajdonviszonyaiban keresendő. Ezek ugyanis nem a városi önkormányzat, hanem a megyei önkormányzat tulajdonában vannak (lásd Kenézy Gyula Kórház), illetve közvetlenül az Országos Egészségbiztosítási Pénztártól és az Oktatási Minisztériumtól (korábban Egészségügyi Minisztériumtól) kapják (kapták) a pénzt (ex-DOTE). Ennek következtében a müködésükhöz szükséges összeg nem fut át a városi költségvetésen, és így nem jelenik meg az önkormányzat bevételei között sem.

A hitel-és kötvénybevételek nagyobb súlya (ez azon kevés források egyike, amelyeknél az egy före jutó érték jelentősen meghaladja az országos átlagot) alapvetően az 1990-es évek közepének gazdálkodási elképzeléseivel magyarázható. A különböző ingatlanok (például az önkormányzat tulajdonába került lakások és telkek) nagyarányú eladása után a város vezetösége továbbra sem akarta nagyobb mértékben megterhelni a lakosságot, és ezért a müködési-fejlesztési kiadások fedezése érdekében különbözö pénzpiaci müveletekbe kezdett. Ennek keretében 1994 és 1995 folyamán jelentős hiteleket vett fel, valamint kötvénykibocsátást is végrehajtott (a hitel- és kötvénybevételek aránya az összbevételböl - az országban szinte egyedülálló módon - 1993-ban és 1994-ben nyilvánosan 10,1\% volt, 1995-ben pedig $11,7 \%$ volt). Ezen lépések ugyanakkor nagymértékben veszélyeztették a város pénzügyi stabilitását, aminek következtében az önkormányzat visszafogta ilyen irányú tevékenységét, és 1996 óta folyamatosan csökkent e forrás szerepe (1998-ban az összbevételből való részesedése már kisebb volt, mint az országos érték-2,8\% ill. 4,2\%). 


\section{A kiadási oldal sajátosságai}

A debreceni önkormányzat költségvetésének kiadási oldalát vizsgálva megállapítható, hogy a müködési kiadások, illetve a támogatások átlagos részaránya az összkiadásokból felülmúlta az országos értéket, míg a fejlesztési-felhalmozási kiadások és az egyéb kiadások részaránya alatta maradt annak (3. táblázat).

\section{TÁBLÁZAT}

A magyarországi önkormányzatok és a debreceni önkormányzat egyesített költségvetésének kiadási oldala (1992-98 közötti évek átlaga, 1992-es áron számolva, a fogyasztói árindexet felhasználva)

(The Expenditure Side of the Budgets of the Hungarian Local Governments and the Local Government of Debrecen, Average of the Years 1992-1998, Adjusted to the Prices of 1992 with the Consumer Price Index)

\begin{tabular}{lcrrr}
\hline & \multicolumn{3}{c}{ A } & \multicolumn{2}{c}{ B } \\
\cline { 2 - 5 } & $\begin{array}{c}\text { Magyar- } \\
\text { ország }\end{array}$ & Debrecen & $\begin{array}{c}\text { Magyar- } \\
\text { ország }\end{array}$ & Debrecen \\
\hline 1. Müködési kiadás & 70,4 & 72,5 & 31433 & 25539 \\
1.1. személyi jellegú kiadás & 29,7 & 30,6 & 13242 & 10786 \\
1.2. munkaadót terhelö járulék & 12,6 & 13,6 & 5631 & 4785 \\
1.3. dologi kiadás & 28,1 & 28,4 & 12560 & 9968 \\
2. Felhalmozási-fejlesztési kiadás & 18,2 & 14,9 & 8138 & 5259 \\
3. Támogatások & 8,0 & 10,7 & 3584 & 3784 \\
3.1. múködési célú pénzeszköz-átadás & 1,7 & 3,1 & 776 & 1077 \\
3.2. társadalom- és szociálpolitikai & 5,3 & 6,9 & 2370 & 2448 \\
$\quad$ juttatások & & & & \\
3.3. egyéb támogatás & 1,0 & 0,7 & 438 & 257 \\
4. Egyéb kiadások & 3,3 & 1,8 & 1493 & 645 \\
Tárgyévi kiadások & 100,0 & 100,0 & 44648 & 35226 \\
\hline A
\end{tabular}

A - az egyes kiadási típusok részesedése az összkiadásból (\%), B - az adott kiadási típus egy lakosra jutó értéke ( $\mathrm{Ft} / \mathrm{fö})$

Forrás: Keményné Koncz 1993; Szelényi 1994; Birkásné Tóth-Szelényi 1995; DobosnéSzelényi 1996; 1997; 1998; és a debreceni önkormányzat költségvetési rendeletei.

A müködési kiadások országosnál némileg magasabb aránya egyértelmúen a város igen jelentős - korábban már többször is megemlített - intézményhálózatával van összefüggésben: az oktatási-kulturális-szociális stb. intézmények müködtetése, valamint a város üzemeltetése (közvilágítás, parkfenntartás stb.) a legtöbb évben a város kiadásainak több mint $70 \%$-át tette ki. Részben ezzel függ össze, részben a korábban említett gyenge központi érdekérvényesítési képességgel magyarázható, hogy az 1992-98 közötti időszakban a város vezetősége alig tudott igazi nagyberuházást elkezdeni, és így a fejlesztési-felújitási kiadások aránya a hét év átlagában lényegesen elmaradt az országos értéktöl. Az egyedüli kivételt az 1995/96-os évek jelentették (a felhalmozási-fejlesztési kiadások aránya ezekben az években $20 \%$ felett volt), amikor három jelentős projekt is lezajlott: Tóth Árpád Gimnázium felépítése, szennyvíztisztító-telep bővítése, villamospálya-rekonstrukció és új villamosok vásárlása. Ezek a kiadások azonban olyan mértékben megterhelték a város költségvetését, hogy a következő két évben már jelentősen visszaszorultak a beru- 
házások, amelyhez az is hozzájárult, hogy a város nem mert hozzányúlni az erre az időszakra már egyre inkább túlméretezetté vált intézményhálózathoz, illetve ekkor kellett elkezdeni a korábban felvett kamatok visszafizetését is.

A támogatások két döntő alkotóelemét a müködési célú pénzeszköz-átadás, valamint a társadalom- és szociálpolitikai juttatások képezik. Mint a táblázatokból is kiderül, mind a két elem aránya lényegesen felülmúlta az országos értéket, amely eltérő okokra vezethető vissza. A müködési célú pénzeszköz-átadás az önkormányzati tulajdonban lévő, illetve az állami tulajdonban lévő, de a lakosság ellátását szolgáló közszolgáltató vállalatok számára átadott összeget foglalja magában, amely azt a célt szolgálja, hogy a lakosságnak kisebb terheket kelljen viselnie. Debrecenben a város méreténél, szerepkörénél fogva ezek a feladatok hatványozottan jelentkeznek (az első típusba tartozik például a Debreceni Közlekedési Vállalat Rt. és a Debreceni Höszolgáltató Rt., míg az utóbbiba a Hajdú Volán Rt.), és ezzel magyarázható ezen kiadási tétel magas aránya.

A társadalom- és szociálpolitikai juttatások a különbözö szociális támogatási formákat (például lakhatási támogatás, rendszeres szociális segély, munkanélküliek jövedelempótló támogatása) foglalják magukban. Ezen kiadási tétel magas aránya mögött véleményünk szerint az a tény áll, hogy bár Debrecenben a munkanélküliek aránya az országos átlag alatt van, a város nagysága miatt igen jelentős a támogatásra szoruló rétegek aránya, akik - valószínủleg magasabb iskolázottságuk, tájékozódottságuk miatt - tisztában is vannak ezekkel a lehetöségekkel

Az egyéb kiadások döntó részét az adósságszolgálat terhei alkotják. Az 1990-es évek elején Debrecen csak korlátozottan élt a hitelek felvételével, illetve kötvények kibocsátásával, és ez a tevékenység csak $1994 / 95$ folyamán élénkült meg. Ennek fényében nem meglepö, hogy a felvett hitelek visszafizetése, mint kiadás csak 1997/98 során jelent meg nagyobb összegként a költségvetésben, de valószínú, hogy a későbbiek során még hosszú ideig jelentős tételt fog alkotni (1998-ban részesedése már $6,2 \%$ volt).

\section{Összegzés}

Összegzésként - és a tanulmány bevezetőjében feltett kérdésekre válaszolva - elmondható, hogy a debreceni költségvetés bevételi és kiadási oldala több területen is eltér az országos viszonyoktól, és ez különböző okokra vezethető vissza. Ezek közül a legfontosabb szerepet a város megyeszékhelyi és regionális központi szerepköre (a normatív állami hozzájárulások és a müködési kiadások magas aránya) és az egészségügyi intézmények tulajdonviszonyai (Társadalombiztosítástól átvett pénzek alacsony aránya) töltötték be. Kisebb fontosságúnak lehet tekinteni a város hosszú ideig gyenge érdekérvényesitö-képességét (a cél- és címzett támogatások valamint az egyéb felhalmozási és tőkebevételek alacsony aránya), a költségvetés állandóan feszitett jellegét (kamatbevételek alacsony aránya) és a város nagyságából adódó jelentös szolgáltatási igényt (mủködési célú pénzeszköz-átadás magas aránya). 


\section{Irodalom}

Adóemelések a nagyvárosokban. (2000) - Vilagggazdaság. január 19.

Birkásné Tóth K.-Szelényi Gy. (1995) Tallózás a helyi önkormányzatok 1994. évi zárszámadásának eredményei között. - Pénzügyi Szemle. 8. 603-624. o.

Debrecen Megyei Jogú Város Közgyülésének 12/l993 (IV. 19.) számú rendelete az 1992. évi költségvetés végrehajtásáról. (1993) Debrecen.

Debrecen Megyei Jogú Város Közgyülésének $20 / 1994$ (V. l6.) Kr. számú rendelete az Önkormányzat 1993. évi zárszámadásáról. (1994) Debrecen.

Debrecen Megyei Jogú Város Közgyúlésének 18/1995 (V. l5.) Kr. számú rendelete az Önkormányzat 1994. évi zarszamadásáról. (1995) Debrecen.

Debrecen Megyei Jogú Város Közgyülésének 42/1996 (VI. 25.) Kr. számú rendelete az Önkormanyzat 1995. évi zárszámadásáról. (1996) Debrecen.

Debrecen Megyei Jogú Város Közgyülésének 8/1997 (IV. 17.) Kr. számú rendelete az Önkormányzat 1996. évi zárszámadásáról. (1997) Debrecen.

Debrecen Megyei Jogú Város Közgyülésének $11 / 1998$ (IV. 30.) Kr. számú rendelete az Önkormányzat 1997. évi zarszámadasáról. (1998) Debrecen.

Debrecen Megyei Jogú Város Közgyülésének $17 / 1999$ (IV. 26.) Kr. számú rendelete az Önkormányzat 1998. évi zárszámadásáról. (1999) Debrecen.

Dobos L-né-Szelényi Gy. (1996) Tallózás a helyi önkormányzatok 1995. évi zárszámadásának eredményei között. - Pénzügyi Szemle. 9. 659-676. o.

Dobos L-né-Szelényi Gy. (1997) Tallózás a helyi önkormányzatok 1996. évi zárszámadásának eredményei között. - Pénzügyi Szemle. 9. 669-684. o.

Dobos L-né-Szelényi Gy. (1998) Tallózás a helyi önkormányzatok 1997. évi zárszámadásának eredményei között. - Pénzügyi Szemle. 6. 425-454. o.

Dobos L-né-Szelényi Gy. (1999) Tallózás a helyi önkormányzatok 1998. évi zárszámadásának eredményei között. - Pénzügyi Szemle. 8. 681-711. o.

Keményné Koncz I. (1993) Önkormányzati zárszámadás 1992. - Pénzügyi Szemle. 9. 697-708. o.

Szelényi Gy. (1994) Tallózás az önkormányzatok 1993. évi zárszámadásának eredményei között. Pénzügyi Szemle. 7. 501-519. o.

\section{THE CHARACTERISTICS OF THE BUDGET OF THE LOCAL GOVERNMENT OF DEBRECEN 1992-1998}

\section{GÁBOR KOZMA}

The local self-governments created after the transformation of regime had to face changed conditions in the area of economy: the receipt and expenditure structure of their budget modified to a great extent, the economic independence of the settlements increased in comparison with the previous period. The paper tries to give an answer to which reasons may explain the deviation of the receipts and expenditures side of the budget of Debrecen from the national data. According to the results, the most important roles were fulfilled by the county seat and regional central roles (the high proportion of the normative state contributions and of the operational expenses) and the ownership relations of the public health institutions (low proportion of Transfers from the Social Security Funds). The long weak ability of the interest enforcement of the city may be regarded as less important (the low proportion of addressed and targeted grants and of the other accumulated and capital incomes), the constantly tightened nature of the budget (low proportion of credits) and the considerable service demand due to the size of the city (high proportion of money financing the operation of local services). 